\title{
COURAGE IN POLITICS
}

A könyv szerkesztői Bódi Ferenc, Andrea Ragusa és Ralitsa Savova. Bódi Ferenc, a Társadalomtudományi Kutatóközpont Politikatudományi Intézetének szenior tudományos munkatársa. Andrea Ragusa (1974-2018) a kortárs történelem professzoraként dolgozott a Sienai Egyetem Nemzetközi és Politikatudományi Tanszéken, valamint a Fondazione di Studi Storici 'Filippo Turati' Intézet igazgatóságának tagja volt. Ralitsa Savova a Társadalomtudományi Kutatóközpont Politikatudományi Intézet külső munkatársa, doktorjelölt; a Storia e Futuro szerkesztőségi bizottságának és az Amelio Tagliaferri folyóirat Nemzetközi Tudományos Testületének tagja.

A Saggistica Kiadó által megjelentetett 200 oldalas könyvben a bemutatkozással együtt tíz tanulmány olvasható kilenc szerzőtől. A kötet alapvetően Andrea Ragusa egyetemi docens tiszteletére és emlékére született. A könyv a politikai bátorság témáját több nézőpontból is vizsgálja, mint a siker, a hit, az erény, a különböző személyiségjegyek vagy a nemek közötti különbségek. Ezek kiválóan érzékeltetik a vitatott téma összetettségét. A tanulmányok kiemelik egy-egy korszak figyelemre méltó szereplőit, akik akkor, abban az időszakban - a szerzők megvilágításában - vakmerően nyúltak a politikához, és merész döntéseket hoztak. Az alapvetően történelmi eseményeket új szempontokból bemutató tanulmányok túllépnek a jelenlegi értelmezés keretein, és a feltárt események egy újfajta olvasatát kínálják fel.

Bódi Ferenc Courage in Politics címủ tanulmánya az 1956-os magyar forradalomra összpontosít. A szerző egyrészt, a bátorság erényének motívumát tanulmányozza, ami a szabadságharcosok feltételezett erkölcsi motivációja, másrészt, a „hamis forradalmár” jelenségét értelmezi. A tanulmány Kádár János személyiségére fókuszál, aki kompromisszumok nélkül vált a „helyreállítás” korszakának vezetöjévé. Bódi Ferenc a következö, Political Anthropological Interpretation of the 1956 Hungarian Revolution címü tanulmányában szintén az 1956-os magyar forradalom értelmezésével foglalkozik, melyben azt vizsgálja, hogy a forradalomban való részvétel bátorság vagy vakmerőség volt-e. A szerző a „hamisság és megtévesztés" ellentétének szembeállításával kíván reagálni a forradalom magyarázatára. A szerző hangsúlyozza, hogy a magyar forradalom 1956-ban valódi kiegyezés nélkül ért véget, az új rendszer hamis értékrendet emelt a valódi erények fölé, ahol a bátorságot a kompromisszumok, az igazságot pedig a hamisság váltotta fel. Szerinte csak az erények biztosítanak olyan közös nyelvet, amely által jó megállapodások születhetnek, a felek megértik és elfogadják egymást, és nem utolsósorban képesek megtalálni a kölcsönös előnyöket. 
Thomas R. Lawson - az amerikai Louisville-i Egyetem professzora és a nemzetközi programok igazgatója - a The Promised Land. A Mountaintop and Political Courage: A View from the Ground címü tanulmányában kifejti, hogy különböző országokban és kultúrákban időtlen idők óta az elnyomás, a hazugságok és a leigázás ellen fellépőket tekintették bátraknak. A szerző a politikai bátorság érzékeltetéséhez egy metaforát használ, miszerint ahhoz, hogy az emberek feljuthassanak a hegy csúcsára, a helyre, ahol többé már nem számítanak elnyomottnak, leigázottnak, és nem kell hamisságokat követniük, ahol a szellemük élhet és kifejezhetik önmagukat, politikai bátorságra van szükség.

Nuno Morgado a geopolitika és a külpolitika szakértője, az Eötvös Loránd Kutatási Hálózat külsö munkatársa, a Budapesti Corvinus Egyetem adjunktusa. Az Anti-communism in Salazar's Portugal and the Hungarian Uprising of 1956 címü tanulmányának célja a portugál kormány és társadalom 1956-os magyar felkelésre adott válaszának vizsgálata.

Kávássy János Elöd a Rendszerváltás Történetét Kutató Intézet és Archívum tudományos munkatársa. A From Sound to Square Silence címü tanulmánya középpontjában az 1956-os magyar forradalom és szabadságharc tragédiája áll. A szerző arra törekszik, hogy bemutassa 1956 egyik elfeledett hősét, Rajki Mártont, aki azt vallotta, hogy a párbeszéd és a konszenzus lényegében az uralkodó kommunista rendszer elnyomásaként és terrorjaként értelmezhetö.

Oross Dániel politológus, 2011-től a Társadalomtudományi Kutatóközpont Politikatudományi Intézetének tudományos munkatársa. A Youth Policy between 1956 and 2016 in Hungary címü tanulmányában azon az állásponton van, hogy az ifjúság fontos szerepet játszott a forradalmi változásokban, de politikai képviseletük mindig is gyenge volt. A tanulmány a fiatalok szerepét mutatja be az 1956-os magyar forradalomban. Szerinte a magyar ifjúságpolitika elnyúló átalakulása még korántsem ért véget, az napjainkban is tartó folyamat, amelynek új kihívásokkal kell számolnia.

A Female Courage címü tanulmány szerzöi: Toldi Andrea nyelvtanár - a Debreceni Egyetem Egészségügyi Kar munkatársa -, Fábián Gergely szociológus - a DE Egészségügyi Kar Társadalomtudományi Tanszékének vezetője -, valamint Thomas R. Lawson amerikai professzor. A szerzők arra hívják fel a figyelmet, hogy egy férfi lehet király, egy csata vezetöje, tábornok vagy lovag, de ahhoz, hogy egy nő politikus legyen, vezető szerepet vállaljon, vagy felemelje a hangját valamiért vagy valakiért, nagy bátorságra van szükség. Hangsúlyozzák, hogy ma egyre több nő vesz részt aktívan a politikai életben, vagy tölt be történelemíró szerepet, és emiatt leginkább furcsának, „másnak” vagy lázadónak tekintik őket.

A kötet utolsó két tanulmányának szerzője Szécsi Árpád, aki PhD-jelölt az Eötvös Loránd Tudományegyetem Államtudományi Doktori Iskolájában. A Pre-history of the Hungarian Democratic Forum as an Intellectual and Political Movement címü tanulmányában az 1990-es szabad választásokat megnyerő párt, a 
Magyar Demokrata Fórum (MDF) szellemi és politikai előzményeire fókuszál, áttekintést ad a látens hálózattá válás meghatározó időszakáról. A From the Tent to the Parliament. The Early Period of the Hungarian Democratic Forum (19871990) címü tanulmányában a szerző megállapítja, hogy az MDF gyökerei - mind szellemi, mind erkölcsi dimenziókban - az 1956-os magyar forradalomra nyúlnak vissza, majd az országos méretủvé növekedett szervezet 1989 nyarán politikai párttá alakult. Az MDF - mint a legnagyobb számú mandátummal rendelkező párt - 1990 tavaszán megnyerte a választásokat, és folytatta ,, a sátortól a parlamentig" tartó történelmi útját.

A tanulmánykötet minden olyan szakember számára hasznos, akik politikatudománnyal vagy történelmi kutatásokkal foglalkoznak. A könyv azoknak ajánlott, akik kritikusan, új nézőpontból kívánják szemlélni a tényszerü történelmi eseményeket.

(Ferenc Bódi - Andrea Ragusa - Ralitsa Savova editors: Courage in Politics. Pisa: Pacini Editore, 2020)

Barnucz Nóra

egyetemi tanársegéd Nemzeti Közszolgálati Egyetem Rendészettudományi Kar Idegennyelvi és Szaknyelvi Lektorátus 